\title{
Streptococcus iniae, a bacterial infection in barramundi Lates calcarifer
}

\author{
E. S. Bromage ${ }^{1, *}$, A. Thomas ${ }^{2}$, L. Owens ${ }^{1}$ \\ ${ }^{1}$ Department of Microbiology and Immunology, James Cook University, Townsville, Queensland 4811, Australia \\ ${ }^{2}$ Department of Primary Industries, Oonoonba, Townsville, Queensland 4811, Australia
}

\begin{abstract}
The cause of ongoing mortality in barramundi Lates calcarifer (Bloch) in seawater culture was identified as Streptococcus iniae by biochemical and physiological tests. This is the first published record of this bacterial species in Australia and the first confirmed report of S. iniae causing mortality in barramundi. The bacterium was highly pathogenic for barramundi when challenged by bath exposure. The pathogen was found to have a $\mathrm{LD}_{50}$ of $2.5 \times 10^{5}$ and $3.2 \times 10^{4}$ colony-forming units at $48 \mathrm{~h}$ and $10 \mathrm{~d}$ respectively. Experimental challenge of barramundi resulted in high levels of mortality $(>40 \%)$ within a $48 \mathrm{~h}$ period. Ten days after the challenge, $S$. iniae could not be isolated from kidney, spleen, liver or eye of surviving fish. However, the organism was easily isolated from the brain of both moribund and healthy fish, indicating that barramundi can carry the bacterium asymptomatically.
\end{abstract}

KEY WORDS: Streptococcus iniae $\cdot$ Lates calcarifer - Disease studies

\section{INTRODUCTION}

It is with increasing regularity that streptococcosis is being identified as the cause of major losses in the aquaculture industry. The syndrome streptococcosis has been used to describe fish disease caused by lactic acid bacteria, including streptococci, enterococci and lactococci (Hawkesford 1997). Recent reviews have indicated that there has been at least 40 separate outbreaks of streptococcosis worldwide (Schmidtke 1995, Bromage 1997, Hawkesford 1997). Streptococcosis appears to have very few limitations in regard to geographic boundaries or host range, with outbreaks occurring in aquaculture facilities worldwide and in many different cultured species. The vast majority of outbreaks due to members of the genus Streptococcus have occurred in cultured fishes including rainbow trout Oncorhynchus mykiss (Hoshina et al. 1958, Bragg \& Broere 1986, Ceschia et al. 1992), yellowtail Seriola quinqueradiata (Minami et al. 1979), tilapia Tilapia spp. (Eldar et al. 1994, Perera et al. 1994), and rabbitfish Siganus canaliculatus (Foo et al. 1985), and more recently an Enterococcus-like bacterium was isolated from moribund freshwater prawns (Cheng et al. 1998).

·E-mail: erin.bromage@jcu.edu.au
There have been several reported outbreaks of streptococcosis in Australia, occurring primarily in cultured rainbow trout (e.g. Carson \& Munday 1990, Carson et al. 1993). The first report of streptococcosis in the tropics of Australia was from an investigation by Queensland Department of Primary Industries Oonoonba Veterinary Laboratory (QDPI OVL) and reported in Moody (1992), who briefly described the involvement of a streptococcal pathogen in mortalities in sea-farmed barramundi.

Since 1992, mortality due to streptococcosis in seacultured barramundi has increased and the pathogen is now considered as the most important bacterial species affecting the successful sea-culture of barramundi in northern Queensland (I. Patch pers. comm. 1997). The disease usually persists as a low-level, chronic infection with mortalities occurring daily, mainly in juvenile fish. The clinical signs of disease are very similar to those described by other authors (Kusuda et al. 1976, Perera et al. 1994), including bilateral exopthalmia, darkened body pigmentation and ascites. However, acute episodic outbreaks occur throughout the warmer months with mortalities reaching $70 \%$ overnight and clinical signs being limited to mild corneal opacity.

This paper reports on the identity of the bacterium responsible for the on-going mortality of sea-cultured 
barramundi, and establishes, via Koch's postulates, that this bacteria is the cause of these outbreaks.

\section{METHODS}

Bacterial isolation. Moribund barramundi displaying clinical signs of the disease were obtained from affected farms and transported live to the laboratory. Bacterial isolation was performed from the brain, spleen, kidney, liver and eye. Swabs from these sites were streaked onto blood agar (BA Oxoid, Basingstoke, UK) supplemented with 5\% sterile sheep's blood (laboratory animal). Bacterial cultures were incubated at $27^{\circ} \mathrm{C}$ for $48 \mathrm{~h}$.

Bacterial characterisation. Bacterial isolates were identified using the classical plate and test tube tests (Smibert \& Krieg 1981, Hardie 1984, Facklam \& Washington 1991, Coleman et al. 1992) and the API 20 STREP identification system (BioMerieux, Marcy l'Etoile, France). Lancefield groupings A-F were performed using the Streptex system (Murex Diagnostics, USA). Isolates of Enterococcus faecalis and Streptococcus pyogenes were run in parallel to the streptococcallike isolates to serve as controls. The API 20 STREP was conducted as per the manufacturers instructions except that the incubation temperature was reduced to $27^{\circ} \mathrm{C}$ to represent the ambient environmental temperature. Test tube tests were performed by suspending the bacterial culture obtained from a BA plate into $5 \mathrm{ml}$ of sterile phosphate buffer saline (PBS), using a sterile swab, until a cell density equal to 4 MacFarlane units was obtained. Bacterial suspension $(100 \mu l)$ was then dispensed into each of the tubes containing the varying substrates and incubated for $24 \mathrm{~h}$ at $27^{\circ} \mathrm{C}$. Reactions were scored positive $(+)$ or negative $(-)$ with regard to colour change by comparison to an uninoculated solution. Two known bacterial controls, E. faecalis and $S$. pyogenes, were characterised simultaneously using both systems.

Fish husbandry under experimental conditions. Barramundi fingerlings of an average total length $100 \mathrm{~mm}$ were obtained from NQ Barramundi (Townsville, Australia). A sample of 15 fish were subject to bacterial isolation as described above to determine the health status of experimental animals.

The experimental infection trials were performed in glass aquaria maintained at a salinity of $35 \mathrm{ppt}$ and $27^{\circ} \mathrm{C}$.

Determination of the lethal dose $50 \%$. Seven groups (6 experimental and 1 control) of 10 barramundi were placed into individual glass aquaria and were allowed to acclimatise over a period of $2 \mathrm{wk}$ before the experiments began. A single bacterial isolate (no. 28-97-L-B) was passaged 3 times through barramundi without cul- ture on hard media following the methods of Eldar et al. (1995a). Following the final passage, a bacterial swab was taken from the brain of the first moribund barramundi, streaked onto BA and incubated for $24 \mathrm{~h}$ at $27^{\circ} \mathrm{C}$. The culture was then re-suspended in PBS until a cell density of $10^{8}$ colony-forming units (cfu) per $\mathrm{ml}$ was achieved. The range of $10^{2}$ to $10^{7}$ was used to provide a broad range of challenge densities. Each group of fish were placed into a $10 \mathrm{l}$ container of seawater containing the appropriate dilution of the bacteria or neat seawater for the control. After an exposure period of $1 \mathrm{~min}$, the fish were removed and placed into their respective aquaria.

Determination of the lethal dose for $50 \%$ of the animals ( $L D_{50}$ ) at $48 \mathrm{~h}$ and $10 \mathrm{~d}$ was conducted using a probit analysis and the mortality curves were compared using survival analysis in the statistical package SPSS (SPSS Inc.).

Experimental challenge of Lates calcarifer with isolates of Streptococcus iniae. Three isolates of $S$. iniae (nos. 48-97-L-K, 28-97-L-B, 21-97-W), were randomly chosen from the isolates obtained from moribund farmed barramundi. Ten fish per isolate were then challenged by bath exposure to $S$. iniae equal to the $\mathrm{LD}_{50}$ at Day 10. All mortalities were recorded, and dead and moribund fish were subject to bacterial isolation. All fish surviving at Day 10 were euthanised and bacterial isolation performed.

\section{RESULTS}

\section{Morphology and characterisation}

Bacterial isolation from 31 moribund barramundi received from the farm revealed that Streptococcuslike isolates could be obtained, in almost pure culture, from the brain of all infected fish (Table 1). The bacterium could also be isolated to varying degrees from all the other organs sampled.

The bacterial isolates were characterised as follows: Gram-positive, catalase negative, oxidase negative cocci, up to $1 \mu \mathrm{m}$ in diameter. The cocci were most often seen occurring as long chains in broth culture. Growth on BA media resulted in small white umbonate colonies that were surrounded by a small area of beta

Table 1 Streptococcus iniae infecting Lates calcarifer. Percentage of recovered isolates from the various organs (5) of 50 naturally infected barramundi

\begin{tabular}{|lccccc|}
\hline & Brain & Kidney & Spleen & Liver & Eye \\
\hline Isolation $(\%)$ & 100 & 92 & 50 & 12 & 28 \\
\hline
\end{tabular}


Table 2. Streptococcus iniae infecting Lates calcarifer. Comparison of the biochemical and physiological characteristics of the present isolates and the results obtained by other authors +: positive, -: negative, ND: not done

\begin{tabular}{|c|c|c|c|c|}
\hline $\begin{array}{r}\mathrm{Pe} \\
\text { of } \\
\mathrm{i}\end{array}$ & $\begin{array}{l}\text { Percentage } \\
\text { of present } \\
\text { isolates } \\
(n=31)\end{array}$ & $\begin{array}{c}\text { Pier } \\
\& \\
\text { Madın } \\
(1976)\end{array}$ & $\begin{array}{l}\text { Kusuda } \\
\text { et al. } \\
\text { (1976) }\end{array}$ & $\begin{array}{c}\text { Stoff- } \\
\text { regen } \\
\text { et al. } \\
(1996)\end{array}$ \\
\hline Haemolysis $(\beta)$ & 100 & + & ND & + \\
\hline Gram stain (+) & 100 & + & + & + \\
\hline Oxidase & 0 & - & - & - \\
\hline Catalase & 0 & - & - & - \\
\hline Motility & 0 & - & - & - \\
\hline Growth in/at: $10^{\circ} \mathrm{C}$ & 6 & + & + & ND \\
\hline $45^{\circ} \mathrm{C}$ & 0 & - & + & - \\
\hline $\mathrm{pH} 9.6$ & 0 & - & + & ND \\
\hline $6.5 \% \mathrm{NaCl}$ & 0 & - & + & + \\
\hline $0 \%$ bile & 0 & - & + & ND \\
\hline Methylene blue milk $0.1 \%$ & 100 & + & + & ND \\
\hline Hydrolysis of: Starch & 100 & + & - & ND \\
\hline Hippurate & 0 & - & - & - \\
\hline Esculin & 100 & + & + & + \\
\hline Voges-Proskauer & 0 & ND & + & - \\
\hline Pyrrolidonylarylamidase & 100 & ND & ND & + \\
\hline$\alpha$-Galactosidase & 0 & ND & ND & ND \\
\hline$\beta$-Glucuronidase & 100 & ND & ND & ND \\
\hline Acid from: Arabinose & 0 & - & - & - \\
\hline Fructose & 100 & + & ND & + \\
\hline Glucose & 100 & + & + & + \\
\hline Inulin & 0 & - & ND & - \\
\hline Lactose & 0 & -- & - & - \\
\hline Mannitol & 100 & + & + & + \\
\hline Mannose & 100 & + & + & ND \\
\hline Raffinose & 0 & - & - & - \\
\hline Ribose & 100 & ND & ND & ND \\
\hline Salicin & 100 & + & + & + \\
\hline Sucrose & 100 & + & - & - \\
\hline Sorbitol & 0 & - & + & - \\
\hline Trehalose & 100 & + & - & + \\
\hline Xylose & 0 & ND & - & - \\
\hline$\beta$-Galactosidase & 0 & ND & ND & ND \\
\hline Alkaline phosphatase & 100 & ND & ND & ND \\
\hline Leucine arylamidase & 100 & ND & ND & ND \\
\hline Arginine dihydrolase & 100 & ND & ND & ND \\
\hline
\end{tabular}

haemolysis and a larger area of alpha haemolysis. In stab culture in BA tubes, all isolates showed complete beta haemolysis.

Isolates obtained from barramundi all displayed identical biochemical characteristics suggesting that they were all the same or a closely related species. Using the commercial API20 STREP system resulted in a profile number of 4562117 , which corresponded to an unacceptable match to Streptococcus equisimilis (APILAB PLUS, BioMuriex). The API 20 STREP system successfully identified the Enterococcus faecalis and Streptococcus pyogenes control isolates.

No variation was observed in regard to the biochemical profile using the commercial and typical testing methods. However, the additional tests performed in the conventional tests allowed identification of the isolates as Streptococcus iniae from comparison with the results from the literature (Pier \& Madin 1976) (Table 2). The present isolates only differed in their inability to grow at $10^{\circ} \mathrm{C}$ after $48 \mathrm{~h}$, with only 2 of the 31 isolates $(6 \%)$ being able to grow at this temperature, whereas the type isolate was reported to have good growth. No reaction was observed from the present isolates in the agglutination test to Lancefield A-F antisera.

\section{Challenge of Lates calcarifer with Streptococcus iniae}

No bacterial pathogens were isolated from any of the fish screened prior to the challenge experiments. The $\mathrm{LD}_{50}$ of the isolate (no. 28-97-L-B) when the fish were challenged via bath exposure was determined to be 2.5 $\times 10^{5} \mathrm{cfu}$ and $3.2 \times 10^{4} \mathrm{cfu}$ at $48 \mathrm{~h}$ and $10 \mathrm{~d}$ respectively. When the fish were subject to the $10 \mathrm{~d} \mathrm{LD}_{50}$, the time to the first death was usually between 16 to $24 \mathrm{~h}$, and in all cases, $40 \%$ of the experimentally challenged fish were dead within $48 \mathrm{~h}$ (Fig. 1). Statistical comparison of the mortality curves revealed that the isolates displayed similar mortality schedules.

\section{Clinical observations}

Fish that died within $48 \mathrm{~h}$ displayed darkened, but patchy body colouration, mild corneal opacity, and an increased ventilation rate. Fish were frequently seen swimming with part of the head out of the water. Before death, fish sank to the bottom, lost the ability to orientate themselves in the water, and appeared to have difficulty ventilating. As the experiment continued beyond $48 \mathrm{~h}$, the typical signs of streptococcosis became increasingly evident. Exopthalmia and corneal

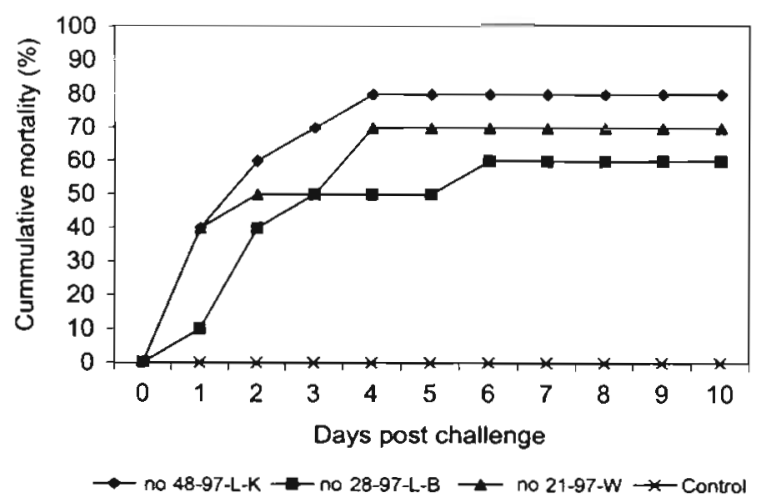

Fig. 1. Streptococcus iniae infecting Lates calcarifer. Comparison of mortality curves of the barramundi challenged with isolates of $S$. iniae 
opacity were always present; often the eye was completely necrotic, resulting in complete blindness. The body of the fish was darkened, and in extreme cases the fish swam in a spiralling motion. Fish were able to respond to physical stimuli, but had little control over movement. Internally, ascites was present, the spleen and kidney were both enlarged when compared to the control animals

Bacterial isolation from dead and moribund fish resulted in pure cultures of Streptococcus iniae from the brain, kidney and spleen. We were unable to isolate $S$. iniae from the spleen or kidney of any surviving fish on Day 10. However, pure isolates were infrequently isolated from the brain of the survivors. No mortality occurred in any of the control fish and the bacterium was not recovered from any organ.

\section{DISCUSSION}

The inability of the present isolates to grow at/in $45^{\circ} \mathrm{C}, 6.5 \% \mathrm{NaCl}, \mathrm{pH} 9.6$ or $40 \%$ bile, excludes the isolates from the genus Enterococcus (Facklam \& Washington 1991). Taxonomic status of the isolate was determined by the comparison of the results with the original report of the type isolate of Streptococcus iniae (Pier \& Madin 1976). The results obtained suggest that the present isolates are biochemically and physiologically similar to the isolate obtained by Pier \& Madin (1976) from freshwater Amazon dolphins. This is the first time that this particular Streptococcus has been reported in Australia, and the first confirmed report of this pathogen causing disease in barramundi. It must be noted that, as $S$. iniae is currently regarded as an exotic pathogen to Australia, there were restrictions against the importation of the ATCC type strain into Australia, and therefore comparitive characterisation could not be performed between the type strain and local isolates.

One previous report of streptococcosis in barramundi occurred in China in 1990 (Huang et al. 1990), where the disease caused mortality ranging between 16.7 and $32.6 \%$. The causative agent of disease was reported as a Streptococcus sp., but variations in the isolates obtained from moribund fish with regards to biochemical tests and serology indicate that more than one species was involved in the outbreak. The isolates obtained from the Chinese barramundi displayed vague similarity in biochemical responses to that of the 2nd isolate of $S$. iniae that was described by Pier et al. (1978) from another captive Amazon freshwater dolphin. Whether or not this isolate is indeed $S$. iniae is uncertain.

Foo et al. (1985) reported a streptococcal infection in cultured rabbit fish Siganus canaliculatus from a farm in Singapore. Barramundi and grouper Epinephelus tauvina were also being cultured at the same location, but did not succumb to the disease. This finding is important as the aetiological agent was later reported by Stoffregen et al. (1996) as a subspecies of $S$. iniae.

The results from the experimental challenge of barramundi with Streptococcus iniae indicate that it can cause morbidity and mortality via a natural route of infection. The subsequent re-isolation of the pathogen from these fish fulfills Koch's postulates and demonstrates that $S$. iniae is indeed the aetiological agent of the disease observed at the farms.

The isolation of the bacterium from the brain of all naturally infected fish, and only from brain of fish surviving experimental challenge highlights that the bacterium can be carried asymptomatically in the brain of fish not displaying signs of the disease. It is well known that antibodies cannot penetrate the blood-brain barrier (Gudkovs 1988). The dectection of an anti-streptococcal humoral immune response has been shown to confer protection against true members of the genus Streptococcus in both tilapia and rainbow trout (Eldar et al. 1995b, 1997). Therefore, if protection against streptococcal infections in barramundi occurs via the same mechanism, this would help explain why the brain remains infected while the other organs test negative for the bacterium. This has serious implications for the culture of barramundi, because even the most diligent farmers removing infected stock will be unable to remove all infected specimens from the farm. These fish will serve as reservoirs of $S$. iniae in an otherwise healthy population.

The isolation of Streptococcus iniae is extremely significant to the future of aquaculture in tropical Australia. Streptococcosis has already shown itself to be a major limiting agent in the successful culture of a variety of temperate-water fish species in many countries including Japan (Kusada et al. 1976), Australia (Carson \& Munday 1990) and South Africa (Boomker et al. 1979). Now, with the appearance of a streptococcal pathogen in the tropics of Australia, there is a significant emerging threat to profitable aquaculture in that region.

\section{LITERATURE CITED}

Boomker J, Imes GD Jr, Cameron CM, Naude TW, Schoonbee HJ (1979) Trout mortalities as a result of Streptococcus infection. Onderstepoort J Vet Res 46:71-77

Bragg RR, Broere JSE (1986) Streptococcosis in rainbow trout in South Africa. Bull Eur Assoc Fish Pathol 6:89-91

Bromage ES (1997) Streptococcus iniae, a bacterial infection in barramundi, Lates calcarifer Bloch. Honours thesis, James Cook University, Townsville

Carson J, Judkovs N. Austin B (1993) Characteristics of an Enterococcus-like bacterium from Australia and South Africa, pathogenic for rainbow trout, Oncorhychus mykiss 
(Walbaum). J Fish Dis 16:381-388

Carson J, Munday BL (1990) Streptococcosis - an emerging disease in aquaculture. Austasia Aquacult Mag 5:32-33

Ceshia G, Giorgetti G, Giavenni R, Sarti M (1992) A new problem for Italian trout farms: strepococcosis in rainbow trout (Oncorhynchus mykiss). Bull Eur Assoc Fish Patho. 12:71-72

Cheng $W$, Chen JC (1998) Isolation and characterization of an Enterococcus-like bacterium causing muscle necrosis and mortality with Macrobrachium rosenbergii in Taiwan. Dis Aquat Org 34:103-108

Coleman G, Efstratiou A, Morrison D (1992) Streptococcus and related organisms. In: Board RG, Jones D, Skinner FA (eds) Identification methods in applied and environmental microbiology. Blackwell Scientific Publications, Oxford, p 221-249

Eldar A, Bejerano Y, Bercovier H (1994) Streptococcus shiloi and Streptococcus difficile: two new Streptococcal species causing meningoencephalitis in fish. Curr Microbiol 28 : $139-143$

Eldar A, Bejerano $Y$, Livolf A, Horovitcz A, Bercovier $H$ (1995a) Experimental streptococcal meningoencephalitis in cultured fish. Vet Microbiol 43:33-40

Eldar A, Shapiro O, Bejerano Y, Bercovier H (1995b) Vaccination with whole cell vaccine and bacterial protein extract protects tilapia against Streptococcus difficile meningoencephalitis. Vaccine 13:867-870

Eldar A, Horovitcz A, Bercovier H (1997) Development and efficacy of a vaccine against Streptococcus iniae infection in farmed rainbow trout. Vet Immunol Immunopath 56: $175-183$

Facklam RR, Washington JA (1991) Streptococcus and related catalase negative Gram positive cocci. In: Balows A, Haus ler WJ Jr, Herrmann KL, Isenberg HD, Shadomy HJ (eds) Manual of clinical microbiology, 2nd edn. American Society for Microbiology, Washington, DC, p 238-257

Foo JTW, Ho B, Lam TJ (1985) Mass mortality in Siganus canaliculatus due to streptococcal infection. Aquaculture 49:185-195

Gudkovs N (1988) Fish immunology, In: Fish diseases: refresher course for veterinarians. Proc 106, Post Graduate Committee in Veterinary Science, University of Sydney, p $531-544$

Editorial responsibility: David Bruno,

Aberdeen, Scotland, UK
Hardie JM (1984) Genus Streptococcus Rosenbach. In: Sneath PHA, Mair NS, Sharp ME, Holt JG (eds) Bergeys manual of systematic bacteriology, Vol 2. Williams and Wilkins, Baltimore, p 1043-1071

Hawkesford T (1997) Microbiological studies of Lactococcus garviae in fish. PhD thesis, University of Tasmania

Hoshina T, Sano T, Morimoto J (1958) A Streptococcus pathogenic to fish. J Tokyo Univ Fish 44:57-68

Huang HT, Hsu JP, Hung HH, Chang WF (1990) Streptococcal infection in maricultured sea bass, Lates calcarifer J Chinese Soc Vet Sci 16:171-180

Kusuda R, Kawai K, Toyoshima T, Komatsu I (1976) A new pathogenic bacterium belonging to the genus Streptococcus, isolated from a epizootic of cultured yellowtail. Bull Jpn Soc Sci Fish 42:1345-1352

Minami T, Nakamura M, Ikeda Y, Ozaki H (1979) A betahaemolytic Streptococcus isolated from cultured yellowtail. Fish Pathol 14:33-38

Moody NG (1992) Experimental infection of barramundi (Lates calcarifer, Bloch) with Bohle Iridovirus. Honours thesis, James Cook University, Townsville, p 3-38

Perera RP, Johnson SK, Collins MD, Lewis DH (1994) Streptococcus iniae associated with mortality of Tilapia nilotica $x$ T. aurea hybrids. J Aquat Anim Health 6:335-340

Pier GB, Madin SH (1976) Streptococcus iniae sp. nov., a beta hemolytic Streptococcus isolated from an Amazon freshwater dolphin, Inia geofrensi. Int J Syst Bacteriol 26: 545-553

Pier GB, Madin SH, Al-Nakeeb S (1978) Isolation and characterisation of a second isolate of Streptococcus iniae. Int $J$ Syst Bacteriol 28:311-314

Schmidtke L (1995) Enterococcus seriolocida: L-forms and antigen recognition by rainbow trout (Oncorynchus mykiss). M Appl Sci thesis, University of Tasmania

Smibert RM, Krieg NR (1981) General characterisation. In Gerhardt P (ed) Manual of methods for general microbiology. American Society for Microbiology, Washington, DC, p 409-433

Stoffregen DA, Backman SC, Perham RE, Bowser PR, Babish JG (1996) Initial disease report of Streptococcus iniae infection in hybrid striped (Sunshine) bass and the successful therapeutic intervention with fluroquinolone antibacterial enrofloxacin. J World Aqua Soc 27:420-434

Submitted: September 14, 1998; Accepted: February 4, 1999 Proofs received from author(s): May 17, 1999 